\title{
Diversity of southern sweet-grass in its natural habitat and in cultivation
}

\author{
KATARZYNA BACZEKK
}

Department of Vegetable and Medicinal Plants

Warsaw University of Life Sciences - SGGW

Nowoursynowska 166

02-787 Warsaw, Poland

phone +48 2259322 58, fax: +48 2259322 32, e-mail: katarzyna_baczek@sggw.pl

\section{Summary}

Introduction: Southern sweet-grass (Hierochloë australis /Schrad./ Roem. \& Schult.) is a wild growing plant. Its leaves, collected from natural sites, are aromatic raw material used in alcohol industry and as a food additive. Their quality is highly diversified.

Objective: The aim of the study was to compare the development of plants and the accumulation of coumarin in leaves of southern sweet-grass occurring in natural environment and introduced into cultivation.

Methods: The in situ and ex situ studies were carried out on the same population. Observations on plant development, morphological parameters of leaves and their weight were made. In the leaves, the level of the coumarin was detected by HPLC-DAD as well as the total contents of flavonoids and phenolic acids were determined spectrophotometrically.

Results: Plants from the natural stand and from cultivation differed significantly in the developmental and morphological parameters as well as in the content of biologically active compounds. Plants from natural site were characterized by a significantly higher coumarin content in leaves, whereas those from cultivation - higher weight of leaves and higher generative reproductive capacity.

Conclusions: In cultivation, $H$. australis is characterized by much less variation in both developmental and yielding parameters, including leaf weight and coumarin content.

Key words: Hierochloë australis, in situ, ex situ, development, yield of leaves, coumarin

\section{INTRODUCTION}

Southern sweet-grass (Hierochloë australis /Schrad./ Roem. \& Schult., Poaceae) is a wild growing tuft grass occurring in north-eastern Europe, mainly in Finland, Estonia, Latvia and Lithuania. In Poland it grows in small, highly dispersed populations, almost exclusively in the Warmia-Mazury 
and Podlasie [1-3]. Most often it can be found on the post-glacial areas in the communities belonging to the acidophilous oak or mixed forests [4-5]. As a typical undergrowth plant, $H$. austarlis prefers well-lit, warm sites, with light, moderately humid and slightly acidic soils $[2,4,6]$. These conditions determine, to some extent, the possibility to introduce the species into cultivation.

$H$. australis has been known and used in prehistoric times. Its seeds were found on archaeological sites of Kujawy, dated to about 5400-5000 BC. Probably, due to specific aroma of leaves, it was used in rituals associated with the worship of deities. For the same reason, in the Middle Ages it was devoted to the cult of the Virgin Mary. In Poland it was called 'grass of the Virgin Mary' and in Germany 'Mariengras' $[7,8]$.

Nowadays, In Poland, $H$. australis has been taken under a partial legal protection [9]. It is also mentioned in the Red List of Vascular Plants, as a taxa threatened with extinction [10]. The species has become rare due to a number of factors, including genetic drift of wild growing populations, overexploitation, and improper harvest technics. However, its leaves, due to their aroma properties, are still utilized in alcohol industry as well as novel food and cosmetic additive. In recent years, the raw material is sought especially as an additive to impart flavor to some confectionery products and meat, mainly poultry, dishes. The specific sweet aroma of these organs is related with the presence of coumarin. The content of this compound is the most important quality factor of raw material.

Southern sweet-grass is often confused with holygrass (Hierochloë odorata /L./ P. Beauv.). Probably the mistakes in their identification results from the fact that both species accumulate coumarin in their leaves (thus are used similarly), and are known under the same common name 'Bison grass'. In contrary to $H$. australis, $H$. odorata is a stolonate grass. Moreover, according to previous investigations, the content of coumarin in its leaves is distinctly lower than in H. australis [11].

The results presented in this paper are a continuation of the research on $H$. australis carried out in Department of Vegetable and Medicinal Plants of Warsaw University of Life Sciences - SGGW, aimed to introduce the species into cultivation [3, 12-15]. According to those research southern sweet-grass grows in situ in small populations, mainly in bright forest sites [3]. Its development and accumulation of coumarin results from genetic diversity of populations $[12,15]$, age of plants [12-14], term of harvest
$[13,14]$ and the environmental factors, including the level of shade $[3,14]$. Ultimately the quality of $H$. australis leaves collected from the wild is hardly predictable.

The aim of this study was to compare the developmental traits as well as the quality of southern sweet-grass leaves collected from natural site and from cultivated plants. To exclude the influence of genetic diversity the investigations were carried out on the same genotype (population).

\section{MATERIAL AND METHODS}

\section{Plant material}

The investigations were carried out on one southern sweet-grass population identified in Podlasie region, in the Eastern Poland (N 52 38.705', E 022 46.600'), described in previous investigation as population 3 [3]. In June 2013, from this population a sample of seeds was collected. To introduce the population into ex situ conditions the seeds were stratified $\left(5^{\circ} \mathrm{C}\right.$ for 2 weeks) and in April, 2014 sown in to the peat substrate of $\mathrm{pH}$ 6.0. After 6 weeks the seedlings were transplanted to planting pots. Field experiment was established the same year from well rooted potted seedlings at the beginning of September. Plant density was $50 \times 30 \mathrm{~cm}$. In 2015 (first year of vegetation) and 2016 (second year of vegetation) the developmental parameters of 15 randomly chosen plants were described and the chemical evaluation of leaves was done. In 2016, on 15 plants randomly chosen from the wild growing maternal population analogous observations and chemical analysis were carried out.

\section{Biometric traits and germination capacity}

The number of fertile shoots, their length, as well as weight of spikelets (in the further part of the paper called seeds) per plant were determined directly before seeds harvest. Thousand seed weight as well as germination capacity were determined according to the International Seed Testing Association [16].

Thousand seed weight was performed in 8 replicates of 100 seeds in each repetition. The result was calculated as the mean weight of 100 seeds, multiplied by 10 .

Germination capacity was determined using sterile $8 \mathrm{~cm}$ Petri dishes filled with filter paper. The seeds were spread out evenly in the dishes. Four replications were used, each of 100 seeds. The experiment was 
performed in a climatic chambers MLR 350 Sanyo, in controlled conditions (irradiation $150 \mu \mathrm{E} / \mathrm{m}^{-2} \mathrm{~s}^{-1}$; temp. $20^{\circ} \mathrm{C}$ for $24 \mathrm{~h}$ ). The germination status was recorded after 14 and 21 days. The seeds were defined as germinated when $2 \mathrm{~mm}$ of radicle had emerged. After germination, the seeds were removed.

The number of leaves, their length and width as well as air-dry weight were determined. The length and width were measured on 20 randomly chosen leaves per plant. Then, the leaves were collected from each plant separately, dried at $35^{\circ} \mathrm{C}$, and subjected to chemical analysis.

\section{Coumarin content}

The preparation of raw materials and extracts for the analysis as well as determination of coumarin (using HPLC-DAD) was carried out according to the methodology described in the article by Bączek et al. [3]. Peak identification was confirmed by comparison of retention time and UV-spectra with coumarin standard. Detection wave for coumarin was $276 \mathrm{~nm}$. The content of this compound was calculated in mg per $100 \mathrm{~g}$ of dry matter $(D M)$.

\section{Total contents of flavonoids and phenolic acids}

Total contents of flavonoids (expressed as quercetin equivalent, \%) and phenolic acids (expressed as caffeic acid equivalent, \%) were determined according to Polish Pharmacopoeia $6^{\text {th }}$ [17]. The analysis were carried out spectrophotometrically. In the case of flavonoids, $0.5 \mathrm{~g}$ of air-dry raw material was extracted, and finally the absorbance was measured at $425 \mathrm{~nm}$. Given phenolic acids, the mass of raw material was $1 \mathrm{~g}$, while the wavelength $490 \mathrm{~nm}$. Results were expressed as percentage of dry matter of raw material.

\section{Statistical analysis}

The results were analyzed using Statistica plus software (StatSoft, Tulsa, USA). The mean values were compared by using one way analysis of variance (ANOVA) followed by Tukey's multiple range test at $\alpha=0.05$ significance level and expressed as mean. The differences between individual means were deemed to be significant at $p<0.05$ and were marked as different letters in columns. The coefficient of variation $(\mathrm{CV}, \%)$ for each analysed parameter was determined as well.

Ethical approval: The conducted research is not related to either human or animal use.

\section{RESULTS AND DISCUSSION}

The spread of southern sweet-grass on natural sites is related to different forms of human activity in the forests, such as clearing or grubbing $[1,4]$. Probably it is related with the higher level of light reaching undergrowth on forest's fellings, required for the seeds formation and germination. In our experiment, wild growing plants produced distinctly lower number of fertile shoots, and lower mass of seeds per plant, than cultivated plants in the second year of vegetation. One-year-old plants produced the lowest number of shoots and thus, the lowest mass of seeds per plant. However, 1000 seed weight and the germination capacity were higher in cultivated plants, irrespectively of their age. Moreover, the plants on natural sites were much more diversified concerning the above mentioned traits than cultivated ones (tab. 1).

Table 1.

Developmental parameters of Hierochloë australis

\begin{tabular}{clccccc}
\hline & Origin and age of plants & $\begin{array}{c}\text { Number of } \\
\text { fertile shoots per } \\
\text { plant }\end{array}$ & $\begin{array}{c}\text { Length of } \\
\text { fertile shoots } \\
{[\mathrm{cm}]}\end{array}$ & $\begin{array}{c}\text { Weight of } \\
\text { seeds per plant } \\
{[\mathrm{g}]}\end{array}$ & $\begin{array}{c}1000 \text { seed } \\
\text { weight [g] }\end{array}$ & $\begin{array}{c}\text { Germination } \\
\text { capacity [\%] }\end{array}$ \\
\hline \multirow{3}{*}{ Mean } & Natural site: wild growing plants & $15.15 \mathrm{~b}$ & $31.67 \mathrm{c}$ & $0.63 \mathrm{~b}$ & $0.503 \mathrm{~b}$ & $15.40 \mathrm{a}$ \\
\cline { 2 - 8 } & Cultivation: one-year-old plants & $7.94 \mathrm{c}$ & $47.55 \mathrm{~b}$ & $0.40 \mathrm{~b}$ & $0.670 \mathrm{ab}$ & $15.73 \mathrm{a}$ \\
\cline { 2 - 8 } & Cultivation: two-year-old plants & $39.94 \mathrm{a}$ & $61.28 \mathrm{a}$ & $1.50 \mathrm{a}$ & $0.763 \mathrm{a}$ & $16.93 \mathrm{a}$ \\
\hline \multirow{3}{*}{$\mathrm{CV}[\%]$} & Natural site: wild growing plants & 80.56 & 34.06 & 81.10 & 28.28 & 46.49 \\
\cline { 2 - 8 } & Cultivation: one-year-old plants & 53.89 & 27.59 & 49.10 & 8.13 & 41.15 \\
\cline { 2 - 8 } & Cultivation: two-year-old plants & 33.73 & 8.23 & 45.38 & 15.60 & 40.58 \\
\hline
\end{tabular}

Means $(n=15)$ marked in columns with different letters differ at $p<0.05$; Tukey's test $\mathrm{CV}$ - coefficient of variation 
The morphological traits of southern sweet-grass, such as the leaf blade surface being a function of the length and width of the leaves, as well as the number of leaves per plant are directly combined with its yielding. In turn, the leaves quality result from the presence of coumarin. According to some authors, both weight of southern sweet-grass leaves and content of coumarin are strictly related to genetic diversity of the species, age of plants, term of harvest, fertilization or light conditions [3, 12-15, 18]. Distinct variability of raw materials collected from wild growing plants is highly unfavorable from the perspective of the industry requirements. High and, what is more important, stable content of coumarin in southern sweet-grass leaves guarantee raw material of high quality. In our experiment, higher weight of leaves was produced by 2 -year-old plants, in comparison with 1-year-old ones. The average mass of the leaves obtained from wild growing plants was two times lower (4.35 g plant $\left.^{-1}\right)$ than from 2-years-old cultivated plants (10.24 $\left.\mathrm{g} \mathrm{plant}^{-1}\right)$. Moreover, plants from natural site were much more diversified $(C V=84.11 \%)$ concerning these parameter (tab. 2). The wild growing plants were characterised by the longest and narrowest leaves, what may be related with a deeper shade on natural site. According to Bączek et al. [3], the average weight of southern sweet-grass leaves collected from natural sites located in the forests, ranges between 1.54 to $11.07 \mathrm{~g}$ air-DM per plant. In turn, in ex situ conditions, depending on the light conditions and term of harvest, it may vary from 6.58 to $19.98 \mathrm{~g}$ air-DM per plant [13].

Southern sweet-grass leaves are a rich source of coumarin compounds, especially coumarin, and phenolics, namely astragalin, rutine, as well as chlorogenic, elagic, ferulic, o-coumaric and rosmarinic acids [12-15]. According to Bączek et al [3], the content of coumarin in wild growing populations vary from

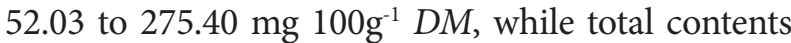
of flavonoids ranges from 0.10 to $0.26 \%$ and phenolic acids from 0.13 to $0.29 \%$. The accumulation of coumarin in individual plants of $H$. australis was also demonstrated earlier. According to Przybył et al. [15], the differences range between 86.08 and $1067.95 \mathrm{mg}$ $100 \mathrm{~g}^{-1} \mathrm{DM}$. It is worth noting that the variability within population is higher in the first year of vegetation as compared to the second one [12].

High content of coumarins or phenolics in plants may be related with biotic or abiotic stress. The above mentioned biologically active compounds serve plants against pathogens, herbivores, ultraviolet or oxidative stress $[19,20]$. High level of coumarin (223.32 mg $100 \mathrm{~g}^{-1} \mathrm{DM}$ ), combined with a high diversity concerned this trait $(C V=49.62 \%)$ in wild growing southern sweet-grass (tab. 3) may be therefore related with the protection of the species against numerous external stressors influencing plants on natural sites. However, such a high diversity concerned coumarin content, being the most important leaf quality marker, is extremely undesirable from the industry point of view. In cultivation, in contrary to wild growing plants, both in first and second year of plant vegetation, the coumarin content in the leaves was lower (62.48 and $105.91 \mathrm{mg}$ $100 \mathrm{~g}^{-1} \mathrm{DM}$, respectively), but much more uniform ( $C V=28.14$ and $27.18 \%$, respectively). In turn, total contents of flavonoids and phenolic acids were distinctly higher in cultivated plants than in wild growing ones. It can be related with the protection of a photosynthetic apparatus of a species naturally adopted to forest conditions, against higher irradiation $[19,20]$. Similarly to coumarin, the diversity concerned the accumulation of phenolics in cultivated plants was distinctly lower than in wild growing ones (tab. 3).

Table 2.

Morphological parameters of Hierochloë australis

\begin{tabular}{llcccc}
\hline & Origin and age of plants & $\begin{array}{c}\text { Number of leaves } \\
\text { per plant }\end{array}$ & Leaf length $[\mathrm{cm}]$ & Leaf width $[\mathrm{cm}]$ & $\begin{array}{c}\text { Air-dry weight of } \\
\text { leaves per plant }[\mathrm{g}]\end{array}$ \\
\hline \multirow{2}{*}{ Mean } & Natural site: wild growing plants & $79.07 \mathrm{~b}$ & $28.28 \mathrm{a}$ & $0.71 \mathrm{a}$ & $4.35 \mathrm{~b}$ \\
\cline { 2 - 6 } & Cultivation: one-year-old plants & $85.07 \mathrm{~b}$ & $26.98 \mathrm{a}$ & $0.80 \mathrm{a}$ & $3.89 \mathrm{~b}$ \\
\cline { 2 - 6 } & Cultivation: two-year-old plants & $151.13 \mathrm{a}$ & $27.65 \mathrm{a}$ & $0.78 \mathrm{a}$ & $10.24 \mathrm{a}$ \\
\hline \multirow{2}{*}{$C V[\%]$} & Natural site: wild growing plants & 51.58 & 13.67 & 10.45 & 84.11 \\
\cline { 2 - 6 } & Cultivation: one-year-old plants & 31.80 & 9.56 & 12.13 & 41.14 \\
\cline { 2 - 6 } & Cultivation: two-year-old plants & 26.98 & 11.80 & 8.95 & 45.25 \\
\hline
\end{tabular}

Means $(n=15)$ marked in columns with different letters differ at $p<0.05$; Tukey's test $\mathrm{CV}$ - coefficient of variation 
Table 3.

Chemical parameters of Hierochloë australis

\begin{tabular}{llccc}
\hline & Origin and age of plants & $\begin{array}{c}\text { Coumarin } \\
{\left[\mathrm{mg} 100 \mathrm{~g}^{-1} \mathrm{DM}\right]}\end{array}$ & $\begin{array}{c}\text { Flavonoids } \\
{[\% \mathrm{DM}]}\end{array}$ & $\begin{array}{c}\text { Phenolic acids } \\
{[\% \mathrm{DM}]}\end{array}$ \\
\hline \multirow{2}{*}{ Mean } & Natural site: wild growing plants & $223.32 \mathrm{a}$ & $0.26 \mathrm{~b}$ & $0.38 \mathrm{~b}$ \\
\cline { 2 - 5 } & Cultivation: one-year-old plants & $62.48 \mathrm{c}$ & $0.37 \mathrm{a}$ & $0.44 \mathrm{ab}$ \\
\cline { 2 - 5 } & Cultivation: two-year-old plants & $105.91 \mathrm{~b}$ & $0.40 \mathrm{a}$ & $0.46 \mathrm{a}$ \\
\hline CV $[\%]$ & Natural site: wild growing plants & 49.62 & 36.27 & 33.77 \\
\cline { 2 - 5 } & Cultivation: one-year-old plants & 28.14 & 27.04 & 21.07 \\
\cline { 2 - 5 } & Cultivation: two-year-old plants & 27.18 & 25.84 & 20.55 \\
\hline
\end{tabular}

Means $(n=15)$ marked in columns with different letters differ at $p<0.05$; Tukey's test $C V-$ coefficient of variation

\section{CONCLUSIONS}

Wild growing plants, in comparison to cultivated ones, were characterized by higher diversity of their reproductive parameters, i.e. the number of fertile shoots and the weight of seeds per plant, as well as the yield of leaves and the content of coumarin. In cultivation the variation in developmental and yielding parameters was distinctly lower.

\section{ACKNOWLEDGEMENTS}

The work was supported by the Polish National Science Centre, project No. NN 310728440.

Conflict of interest: Author declares no conflict of interest.

\section{REFERENCES}

1. Nowiński M. Dzieje Upraw i Roślin Leczniczych. Warszawa, 1980:207-208.

2. Gawłowska J, Sulma T, Wierzchowska-Renke K. Turówka wonna (Hierochloë odorata) i turówka leśna (Hierochloë australis) - zasoby i zagrożenia. Chrońmy Przyr Ojcz 1989; 5(6):60-69.

3. Bączek K, Angielczyk M, Przybył JL, Kosakowska O, Ejdys M, Węglarz Z. Variability of southern sweet-grass (Hierochloë australis /Schrad./ Roem. $\&$ Schult.) wild growing populations occurring in eastern Poland. Herba Pol 2015; 61(3):23-36. doi: http://dx.doi.org/10.1515/hepo-2015-0020

4. Weimarek G. Numerical analysis of the floristic composition of localities including Hierochloë
(Poaceae) species in Northern Europe. Vegetatio 1981; 44(2):101-135.

5. Matuszkiewicz W. Przewodnik do Oznaczania Zbiorowisk Roślinnych Polski. Warszawa, 2011.

6. Ciosek MT. Hierochloë australis (Poaceae) in Nizina Mazowiecko-Podlaska (E Poland). Fragm Flor et Geobot 1996; 41(2):585-588.

7. Hegi G. Illustrierte Flora von Mittel Europa. Pteridophyta, Gymnospermae und Monocotyledones I. München, 1965.

8. Bieniek A. Archaeobotanical analysis of some early Neolithic settlements in the Kujawy region, central Poland, with potential plant gathering activities emphasised. Veg Hist Archaeobot 2002; 11(1):33-40.

9. Rozporządzenie Ministra Środowiska $\mathrm{z}$ dnia 9 października 2014 r. w sprawie ochrony gatunkowej roślin (Dz. U. z 2014 r., poz. 1409).

10. Zarzycki K, Szeląg Z, Mirek Z, Wojewoda W. Red List of the Vascular Plants in Poland: Czerwona Lista Roślin Naczyniowych w Polsce. Kraków, 2006:9-20.

11. Sulma T, Wierzchowska-Renke K. Badanie ziela turówki (żubrówki) Herba Hierochloë. II. Zawartość kumaryny w zielu turówki wonnej Hierochloë odorata Wahlb. i turówki leśnej - Hierochloë australis Roem et Schult. w okresie wegetacji. Acta Polon Pharm 1973; 30(3):317-323.

12. Węglarz Z, Geszprych A, Angielczyk M, Pawełczak A. Wstępne badania nad plonowaniem i wewnątrzgatunkową zmiennością chemiczną 
turówki leśnej (Hierochloë australis (Schrad.) Roem. et Schult.). Zesz Probl Post Nauk Roln 2004; 497:621-626.

13. Podyma W, Bączek K, Angielczyk M, Przybył JL, Węglarz Z. The influence of shading on the yield and quality of southern sweet-grass (Hierochlö̈ australis (Schrad.) Roem. et Schult.) raw material. Herba Pol 2010; 56:14-19.

14. Bączek K, Angielczyk M, Mosakowska K, Kosakowska O, Węglarz Z. Setting of southern sweetgrass plantation with stem cuttings obtained by division of maternal plants. Herba Pol 2014; 60(4):9-21. doi: http://dx.doi.org/10.1515/hepo2015-0001

15. Przybył JL, Paczesna E, Angielczyk M, Bączek K, Podyma W, Geszprych A, Węglarz Z. Intraspecific variability of southern sweet-grass (Hierochloë australis/ Schrad./ Roem. et Schult.) wild growing in Poland. Acta Hort 925; 2011:89-95.

16. ISTA. International Rules for Seed Testing. International Seed Testing Association 2014.
17. Polish Pharmacopoeia VI. Polskie Towarzystwo Farmaceutyczne. Warszawa, 2002:150, 896.

18. Wierzchowska-Renke K. Wpływ nawożenia wybranymi pierwiastkami na sezonową zawartość kumaryny i niektórych makroi mikroelementów w zielu Hierochloë australis. Ann Acad Med Gedan 1993; 23:27-35.

19. Meyer S, Cerovic ZG, Goulas Y, Montpied P, Demotes-Mainard S, Bidel PR et al. Relationship between optically assessed polyphenols and chlorophyll contents, and leaf mass per area ratio in woody plants: a signature of the carbon-nitrogen balance within leaves? Plant Cell and Environ 2006; 29:1338-1348.

20. Karimi E, Jaafar HAZE, Ghasemzadeh A, Ibrahim MH. Light intensity effects on production and antioxidant activity of flavonoids and phenolic compounds in leaves, stems and roots of three varieties of Labisia pumila Benth. Aust J Crop Sci 2013; 7(7):1016-1023.

\title{
Zróżnicowanie turówki leśnej w warunkach jej naturalnego występowania i w uprawie
}

\author{
KATARZYNA BĄCZEK
}

Katedra Roślin Warzywnych i Leczniczych

Szkoła Główna Gospodarstwa Wiejskiego w Warszawie

ul. Nowoursynowska 166

02-787 Warszawa

tel. +48 2259322 58, fax +482259322 32, e-mail: katarzyna_baczek@sggw.pl

\section{Streszczenie}

Wstęp: Turówka leśna (Hierochloë australis /Schrad./ Roem. \& Schult.) jest rośliną dziko rosnącą. Jej liście, zbierane ze stanowisk naturalnych, są surowcem wykorzystywanym w przemyśle spirytusowym oraz jako dodatek do żywności. Ich jakość jest bardzo zróżnicowana.

Cel: Celem pracy było porównanie rozwoju roślin i gromadzenia się kumaryny w liściach turówki leśnej występującej w środowisku naturalnym i wprowadzonej do uprawy. 
Metody: Badania in situ i ex situ przeprowadzono na tej samej populacji. Wykonano obserwacje dotyczące rozwoju roślin, parametrów morfologicznych liści oraz ich masy. W liściach oznaczono zawartość kumaryny metodą HPLC-DAD oraz ogólną zawartość flawonoidów i kwasów fenolowych metodą spektrofotometryczną.

Wyniki: Rośliny ze stanowiska naturalnego i z uprawy różniły się wyraźnie opisanymi w pracy parametrami rozwojowymi, morfologicznymi oraz zawartością związków biologicznie aktywnych. Rośliny ze stanowisk naturalnych charakteryzowały się wyraźnie wyższą zawartością kumaryny w liściach, a z uprawy wyższą masą liści oraz wyższą generatywną zdolnością reprodukcyjną.

Wnioski: W warunkach uprawy $H$. australis charakteryzuje się znacznie mniejszym zróżnicowaniem zarówno parametrów rozwojowych, jak i plonotwórczych, w tym masy liści oraz zawartości w nich kumaryny.

Słowa kluczowe: Hierochloë australis, in situ, ex situ, rozwój, plon liści, kumaryna 